\title{
Значення факторів ризику, пов'язаних з особливостями перебігу гонартрозу, у прогнозуванні віддалених результатів монокондилярного ендопротезування колінного суглоба
}

\author{
М.М. Маціпура \\ Вінницький національний медичний університет ім. М.І. Пирогова, Вінниця, Україна
}

\begin{abstract}
Анотація. Мета: встановити прогностичну цінність факторів ризику, пов'язаних з особливостями перебігу гонартрозу, щодо віддалених результатів монокондилярного ендопротезування колінного суглоба. Об'єкт і методи дослідження. Проаналізовано віддалені результати монокондилярного ендопротезування колінного суглоба у 99 пацієнтів із гонартрозом з переважним ураженням медіального відді-

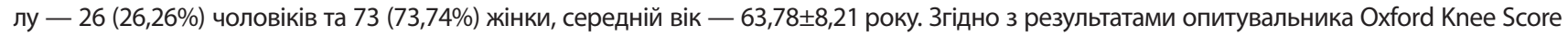
сформовано 4 групи пацієнтів. У 1-шу групу включено 62 (62,63\%) пацієнти без проявів прогресування гонартрозу у віддалений період. Легкі прояви гонартрозу встановлено у 23 (23,23\%) хворих 2-ї групи, помірні - у 10 (10,10\%) обстежених 3-ї групи, у 4 (4,04\%) пацієнтів 4-ї

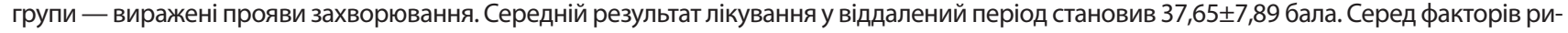
зику оцінювали патогенетичний варіант остеоартрозу, наявність попередніх операцій в ділянці суглоба, стадію, тривалість захворювання до операції та тривалість післяопераційного періоду. Для статистичного аналізу використовували програму «Statistica 13». Peзультати. Встановлено, що тривалість захворювання до операції $\leq 5$ років (відношення шансів (ВШ) 2,70; 95\% довірчий інтервал (ДІ) 1,11-6,58; $p=0,02$ ) та тривалість післяопераційного періоду $\leq 5$ років (ВШ 5,01; 95\% ДІ 1,90-13,20; $\mathrm{p}=0,0007$ ) підвищують шанси щодо відсутності прогресування гонартрозу у віддалений період. Натомість наявність попередніх операцій в ділянці колінного суглоба (ВШ 12,00; 95\% ДІ 1,15-125,52; $\mathrm{p}=0,02)$ асоційована $з$ прогресуванням захворювання. Висновок. Доведено високу прогностичну цінність факторів ризику, пов'язаних з особливостями перебігу гонартрозу, щодо оцінки віддалених результатів монокондилярного ендопротезування колінного суглоба.

Ключові слова: монокондилярне ендопротезування, колінний суглоб, гонартроз, фактори ризику, дегенеративно-дистрофічні захворювання суглобів.
\end{abstract}

\section{Вступ}

Остеоартроз колінного суглоба (КС) - найбільш поширений патологічний стан у структурі дегенеративно-дистрофічних захворювань суглобів. У більшості пацієнтів із гонартрозом діагностують ізольоване ураження одного з відділів суглоба. Варіантом вибору в таких випадках $\epsilon$ використання методики одновиросткової артропластики, яка асоційована з нижчими показниками післяопераційного болю та більш коротким відновним періодом, порівняно з результатами тотального ендопротезування КС. Крім того, в результаті тривалих спостережень доведено достовірно кращі функціональні результати монокондилярного ендопротезування (МKЕ) та вищі показники якості життя пацієнтів порівняно із застосуванням тотальної артропластики.

Зазначимо, що пацієнти у віддалений період після одновиросткової артропластики більш схильні забувати про імплантований штучний суглоб у повсякденному житті, що зумовлено вищою спорідненістю кінематики природного суглоба та одновиросткового ендопротезу порівняно з тотальним його аналогом. Збереження власних зв'язок КС під час монокондилярної артропластики $\epsilon$ ключем до відновлення механіки рухів, схожої до кінематики природного здорового суглоба [1].

Проблема вибору між методами одновиросткової чи тотальної артропластики КС у схемі лікування гонартрозу залишається темою численних дискусій [2]. У багатьох дослідженнях вказані переваги MKE [3-5], однак необхідно зазначити і недоліки, пов'язані з цією хірургічною технікою. Незважаючи на швидше відновлення, нижчу частоту ускладнень та кращі функціональні результати, методика одновиросткової артропластики пов'язана з високим ризиком ревізійного ендопротезування, частота якого втричі вища порівняно з наслідками тотальної заміни суглобових поверхонь. Високий відсоток невдач пов'язаний з низькою частотою виконання подібних втручань та недотриманням стро- гих показань до ії застосування. У структурі ендопротезування КС частка MKE становить лише 5-10\%. Крім того, вища частота ревізійного ендопротезування зафіксована у хірургів з низьким досвідом виконання подібних втручань $[4,6]$. На противагу цьому деякі дослідники доводять безпеку виконання MKЕ в амбулаторних умовах, що, на їх думку, зумовить серйозні фінансові заощадження в системі охорони здоров'я [3].

Зважаючи на невпинне підвищення частоти дегенеративно-дистрофічних захворювань КС та, відповідно, збільшення потреби у проведенні артропластичних втручань, проблема подальшого вивчення методики МKE KC $\epsilon$ актуальною. Цікавим $\epsilon$ дослідження факторів ризику, які пов'язані з особливостями перебігу дегенеративно-дистрофічного процесу та визначення їх впливу на віддалені результати лікування.

Мета: встановити прогностичну цінність факторів ризику, пов'язаних з особливостями перебігу дегенеративно-дистрофічного процесу, щодо віддалених результатів MKE КС.

\section{Об'єкт і методи дослідження}

Проаналізовано віддалені результати лікування 99 пацієнтів, яким виконано МKE KC з приводу гонартрозу з переважним ураженням медіального відділу. Усі хворі перебували на стаціонарному лікуванні в травматологічному відділенні КНП «Вінницька міська клінічна лікарня швидкої медичної допомоги» в період 2009-2019 рр. У досліджувану групу включено $26(26,26 \%)$ чоловіків та 73 (73,74\%) жінки. Середній вік пацієнтів становив 63,78 $\pm 8,21$ року. Більшість пацієнтів - особи похилого (60-74 роки) - $60(60,61 \%)$ та середнього (45-59 років) 30 (30,30\%) віку. У досліджувану групу також включено 8 (8,08\%) пацієнтів старечого (75-90 років) та 1 (1,01\%) - молодого (2544 роки) віку.

Результати лікування оцінювали за допомогою опитувальника Oxford Knee Score. Згідно з отриманими результатами сформо- 
вано 4 групи пацієнтів. У 1-шу групу включено 62 (62,63\%) пацієнти, прояви прогресування гонартрозу в яких були відсутні. Легкі прояви гонартрозу встановлено у 23 (23,23\%) хворих 2-ї групи, помірні - у 10 (10,10\%) обстежених 3-ї групи. У 4 (4,04\%) пацієнтів, які включені до 4-ї групи, виявлено виражені прояви дегенеративно-дистрофічного ураження КС. Середній результат лікування у віддалений період становив 37,65+7,89 бала.

Серед факторів ризику, пов'язаних з особливостями перебігу дегенеративно-дистрофічного процесу, оцінювали патогенетичний варіант остеоартрозу, наявність попередніх оперативних втручань в ділянці досліджуваного суглоба, стадію гонартрозу, тривалість захворювання до операції та тривалість післяопераційного періоду.

Розподіл досліджуваної вибірки згідно з тестом Колмогорова - Смірнова відрізнявся від нормального $(p<0,05)$. При порівнянні показників клінічних груп використовували непараметричний критерій Краскела - Уолліса. Для вимірювання зв'язку між величинами застосовували коефіцієнт рангової кореляції Кендала (т). Основні фактори ризику, пов'язані з особливостями перебігу дегенеративно-дистрофічного процесу, та їх прогностичну цінність встановлювали, використовуючи статистичну модель логістичної регресії, шляхом розрахунку відношення шансів (ВШ) та 95\% довірчого інтервалу (ДІ). Вірогідність безпомилкового прогнозу визначали при $p<0,05$. Для статистичного аналізу отриманих даних використовували програму «Statistica 13».

\section{Результати та їх обговорення}

у більшості пацієнтів встановлено первинний остеоартроз - $83(83,84 \%)$, у $16(16,16 \%)-$ вторинний, у тому числі у $12(12,12 \%)$ - післятравматичний, ще у 4 (4,04\%) - гонартроз після перенесеного асептичного некрозу виростка стегнової кістки (табл. 1). Попередні оперативні втручання в ділянці ендопротезованого КС встановлено у $22(22,22 \%)$ пацієнтів. Достовірної відмінності в частоті виявлених патогенетичних варіантів остеоартрозу з урахуванням прогресування захворювання не визначено ( $>0,05)$. Попередні операції на КС відмічені в анамнезі у більшості пацієнтів 4-ї групи - 3 (75,0\%), 10 (16,13\%) обстежених 1-ї, 6 (26,09\%) - 2-ї та 3 (30,0\%) - 3-ї групи; відмінність між показниками статистично значуща $(p=0,04)$. Крім того, встановлено, що наявність попередніх операцій на КС асоційована зі збільшенням тяжкості гонартрозу у віддалений період, що підтверджено наявністю прямого слабкого кореляційного зв'язку між показниками ( $\tau=+0,21 ; \mathrm{p}=0,002)$.

У більшості осіб - 74 (74,75\%) на момент проведення МKE діагностовано гонартроз III, у решти 25 (25,25\%) - II стадії. II стадію дегенеративно-дистрофічного процесу встановлено у більшості осіб 2-ї групи - 7 (30,43\%), 15 (24,19\%) - 1-ї, 2 (20,00\%) - 3-ї та $1(25,00 \%)$ пацієнта 4-ї групи. У $47(75,81 \%)$ пацієнтів 1-ї групи, 16 (69,57\%) - 2-ї, 8 (80,00\%) - 3-ї та 3 (75,00\%) - 4-ї виявлено гонартроз III стадії. У групах достовірної відмінності у частоті дегенеративно-дистрофічного ураження КС II та III стадії не встановлено $(p=0,92)$.

Середня тривалість захворювання до проведення MKE становила 7,12 4,56 року. У пацієнтів 4-ї групи тривалість дегенеративно-дистрофічного процесу становила $16,25 \pm 4,79$, у 3-й $10,10 \pm 5,90$, у 2-й $-9,22 \pm 4,95$ року. У хворих 1-їгрупи зафіксовано найменшу тривалість захворювання $-5,27 \pm 2,50$ року. При порівнянні отриманих показників у групах пацієнтів з урахуванням отриманих результатів лікування встановлено достовірну відмінність ( $<<0,00001)$. Доведено, що більша тривалість дегенеративно-дистрофічного процесу до проведення МКЕ пов'язана з достовірно гіршими результатами лікування у віддалений період ( $\tau=+0,39 ; p \leq 0,000001)$.

Тривалість дегенеративно-дистрофічного процесу $\leq 5$ років встановлено у 31 (50,0\%) - 1-ї, 7 (30,43\%) - 2-ї та $3(30,0 \%)-$ 3-ї групи (табл. 2). У більшості обстежених — 58 (58,59\%) — тривалість захворювання перевищувала 5 років: у 31 (50,0\%) пацієнта 1-ї, $16(69,6 \%)-2-і ̈, 7$ (70,0\%) — 3-ї та усіх хворих 4-ї групи 4 (100,0\%). При порівнянні частотних показників поширеності досліджуваних факторів ризику у групах пацієнтів з урахуван-
Таблиця 1 Характеристика частоти факторів, зумовлених захворюванням, з урахуванням віддалених результатів лікування

\section{Група}

\begin{tabular}{|c|c|c|c|c|c|}
\hline \multirow[b]{2}{*}{ Фактор ризику } & \multicolumn{5}{|c|}{ Ірупа } \\
\hline & $\begin{array}{c}\text { 1-ша }(n=62), \\
n(\%)\end{array}$ & $\begin{array}{c}2-r a(n=23), \\
n(\%)\end{array}$ & $\begin{array}{c}\text { 3-тя }(n=10), \\
n(\%)\end{array}$ & $\begin{array}{c}\text { 4-та }(n=4), \\
n(\%)\end{array}$ & $\mathbf{p}$ \\
\hline \multicolumn{6}{|c|}{ Етіопатогенетичні фактори } \\
\hline Первинний & $50(80,65)$ & $19(82,61)$ & $10(100,0)$ & $4(100,0)$ & 0,36 \\
\hline Вторинний & $12(19,35)$ & $4(17,39)$ & $0(0,00)$ & $0(0,00)$ & 0,36 \\
\hline Після асептичного некрозу & $4(6,45)$ & $0(0,00)$ & $0(0,00)$ & $0(0,00)$ & 0,48 \\
\hline Післятравматичний & $8(12,90)$ & $4(17,3)$ & $0(0,00)$ & $0(0,00)$ & 0,47 \\
\hline Попередні операції & $10(16,13)$ & $6(26,09)$ & $3(30,00)$ & $3(75,00)$ & $0,04^{*}$ \\
\hline \multicolumn{6}{|c|}{ Стадія захворювання за Kellgren — Lawrence } \\
\hline II & $15(24,19)$ & $7(30,43)$ & $2(20,00)$ & $1(25,00)$ & 0,92 \\
\hline III & $47(75,81)$ & $16(69,57)$ & $8(80,00)$ & $3(75,00)$ & 0,92 \\
\hline
\end{tabular}

*Встановлено достовірну відмінність значень при $\mathrm{p} \leq 0,05$.

Таблиця 2 Характеристика тривалості захворювання та післяопераційного періоду з урахуванням віддалених результатів лікування

\begin{tabular}{|c|c|c|c|c|c|}
\hline \multirow[b]{2}{*}{ Фактор ризику } & \multicolumn{5}{|c|}{ Група } \\
\hline & $\begin{array}{c}1 \text {-ша } \\
(n=62)\end{array}$ & $\begin{array}{c}2-r a \\
(n=23)\end{array}$ & $\begin{array}{c}\text { 3-тя } \\
(n=10)\end{array}$ & $\begin{array}{c}\text { 4-та } \\
(n=4)\end{array}$ & $\mathbf{p}$ \\
\hline \multicolumn{6}{|c|}{ Тривалість захворювання до операції } \\
\hline$M \pm S D$ & $5,27 \pm 2,50$ & $9,22 \pm 4,95$ & $10,10 \pm 5,90$ & $16,25 \pm 4,79$ & $<0,00001^{*}$ \\
\hline$\leq 5$ років, $\mathbf{n}(\%)$ & $31(50,00)$ & $7(30,43)$ & $3(30,00)$ & $0(0,00)$ & 0,10 \\
\hline$>5$ років, $\mathbf{n}(\%)$ & $31(50,00)$ & $16(69,57)$ & $7(70,00)$ & $4(100,00)$ & 0,10 \\
\hline \multicolumn{6}{|c|}{ Тривалість післяопераційного періоду } \\
\hline$M \pm S D$ & $3,21 \pm 1,98$ & $4,35 \pm 2,77$ & $5,20 \pm 3,39$ & $6,50 \pm 2,52$ & $0,04^{*}$ \\
\hline$\leq 5$ років, $\mathbf{n}(\%)$ & $53(85,48)$ & $14(60,87)$ & $5(50,00)$ & $1(25,00)$ & $0,003^{*}$ \\
\hline$>5$ років, $\mathbf{n}(\%)$ & $9(14,52)$ & $9(39,13)$ & $5(50,00)$ & $3(75,00)$ & $0,003^{*}$ \\
\hline
\end{tabular}

*Встановлено достовірну відмінність значень при $p \leq 0,05$.

ням отриманого результату лікування достовірної відмінності не встановлено $(p=0,10)$.

Аналізуючи віддалені результати з урахуванням тривалості післяопераційного періоду, доведено достовірну відмінність значень у групах $(\mathrm{p}=0,04)$. Найменшу тривалість післяопераційного періоду зафіксовано у хворих 1-ї групи - 3,21土1,98 року,

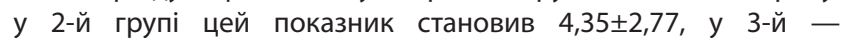

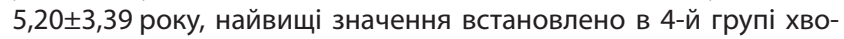

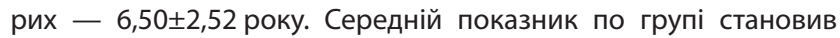

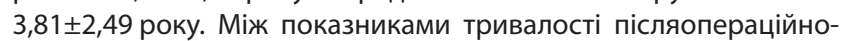
го періоду та віддаленими результатами лікування встановлено прямий слабкий кореляційний зв'язок ( $\tau=+0,23 ; p=0,0007)$, що свідчить про гірші результати лікування у пацієнтів із більшою тривалістю віддаленого періоду.

Оцінюючи прогностичну цінність таких етіологічних факторів, як патогенетичний варіант остеоартрозу, стадія дегенеративно-дистрофічного процесу у формуванні віддалених результатів лікування, достовірного впливу не встановлено ( $>>0,05)$, натомість наявність попереднього оперативного втручання в ділянці досліджуваного КС достовірно підвищує ризик розвитку вираженого гонартрозу у віддалений період після МКE (ВШ 12,00; 95\% ДІ 1,15-125,52; p=0,02) (табл. 3).

Достовірно вищі шанси щодо відсутності проявів гонартрозу у віддалений період встановлено у пацієнтів з тривалістю захворювання в доопераційний період $\leq 5$ років (ВШ 2,70; 95\% ДІ 1,11-6,58; $p=0,02)$, у хворих з більш тривалим періодом шанси відсутності проявів гонартрозу нижчі (ВШ 0,37; 95\% ДІ 0,15-0,90; $\mathrm{p}=0,02)$ (табл. 4).

Тривалість післяопераційного періоду $\leq 5$ років асоційована з вищими шансами щодо відсутності проявів гонартрозу у віддалений період (ВШ 5,01; 95\% ДІ 1,90-13,20; $p=0,0007)$, більша тривалість періоду достовірно знижує подібні шанси (ВШ 0,20; 95\% ДІ 0,08-0,53; $p=0,0007)$. 
Таблиця 3 Прогностична цінність факторів, зумовлених захворюванням, з урахуванням віддалених результатів лікування

\begin{tabular}{|c|c|c|c|c|}
\hline \multirow{2}{*}{ Фактор } & \multicolumn{4}{|c|}{ Група } \\
\hline & 1-ша $(n=62)$ & 2 -ra $(n=23)$ & 3-тя $(n=10)$ & 4-тa $(n=4)$ \\
\hline \multicolumn{5}{|c|}{ Етіопатогенетичні фактори } \\
\hline Первинний & $p=0,25$ & $p=0,85$ & $p=0,05$ & $p=0,23$ \\
\hline Вторинний & $p=0,25$ & $p=0,85$ & $p=0,05$ & $p=0,23$ \\
\hline Після асептичного некрозу & $p=0,049$ & $p=0,14$ & $p=0,35$ & $p=0,56$ \\
\hline Післятравматичний & $p=0,76$ & $p=0,39$ & $p=0,10$ & $p=0,30$ \\
\hline Попередні операції & $p=0,06$ & $p=0,62$ & $p=0,55$ & $\begin{array}{c}\text { ВШ } 12,0 ; \\
95 \% \text { ДI 1,15-125,52; } \\
\text { p=0,02* }\end{array}$ \\
\hline \multicolumn{5}{|c|}{ Стадія захворювання за Kellgren — Lawrence } \\
\hline$\|$ & $p=0,75$ & $p=0,52$ & $p=0,68$ & $p=0,99$ \\
\hline III & $p=0,75$ & $p=0,52$ & $p=0,68$ & $p=0,99$ \\
\hline
\end{tabular}

*Встановлено достовірну відмінність значень при $p \leq 0,05$.

Таблиця 4 Прогностична цінність тривалості захворювання та післяопераційного періоду з урахуванням віддалених результатів лікування

\begin{tabular}{|c|c|c|c|c|}
\hline \multirow{2}{*}{ Фактор } & \multicolumn{4}{|c|}{ Група } \\
\hline & 1-ша $(n=62)$ & $2-r a(n=23)$ & 3-тя $(n=10)$ & 4-та $(n=4)$ \\
\hline \multicolumn{5}{|c|}{ Тривалість захворювання до операції } \\
\hline$\leq 5$ років & $\begin{array}{c}\text { ВШ 2,70; } \\
95 \% \text { मा 1,11-6,58; } \\
p=0,02^{*}\end{array}$ & $p=0,22$ & $p=0,43$ & $p=0,04$ \\
\hline$>5$ років & $\begin{array}{c}\text { ВШ } 0,37 ; \\
95 \% \text { मा } 0,15-0,90 ; \\
p=0,02^{*}\end{array}$ & $p=0,22$ & $p=0,43$ & $p=0,04$ \\
\hline \multicolumn{5}{|c|}{ Тривалість післяопераційного періоду } \\
\hline$\leq 5$ років & $\begin{array}{c}\text { ВШ } 5,01 ; \\
95 \% \text { ДI 1,90-13,20; } \\
p=0,0007^{*}\end{array}$ & $p=0,12$ & $p=0,09$ & $\begin{array}{c}\text { ВШ } 0,11 ; \\
95 \% \text { मІ } 0,01-1,11 ; \\
p=0,04\end{array}$ \\
\hline$>5$ років & $\begin{array}{c}\text { ВШ } 0,20 ; \\
95 \% \text { Al 0,08-0,53; } \\
\text { p=0,0007* }\end{array}$ & $p=0,12$ & $p=0,09$ & $\begin{array}{c}\text { ВШ } 9,39 ; \\
95 \% \text { ДI 0,90-97,54; } \\
\text { p=0,04 }\end{array}$ \\
\hline
\end{tabular}

*Встановлено достовірну відмінність значень при $\mathrm{p} \leq 0,05$.

\section{Висновки}

У результаті проведеного дослідження встановлено високу прогностичну цінність таких факторів, як наявність попередніх оперативних втручань в ділянці КС, тривалість захворювання до операції та тривалість післяопераційного періоду щодо оцінки віддалених результатів МКЕ.

До факторів, які підвищують шанси щодо відсутності ознак прогресування гонартрозу у віддалений період, належать тривалість захворювання до операції $\leq 5$ років (ВШ 2,70; 95\% ДІ 1,11$6,58 ; \mathrm{p}=0,02)$ та тривалість післяопераційного періоду $\leq 5$ років (ВШ 5,01; 95\% ДІ 1,90-13,20; $p=0,0007$ ).

Доведеним фактором, який асоційований з вираженими проявами гонартрозу у віддалений період, $\epsilon$ наявність попередніх операцій на КС в анамнезі (ВШ 12,00; 95\% ДІ 1,15-125,52; p=0,02).

\section{Конфлікт інтересів}

Відсутній.

\section{Список використаної літератури}

1. Presti M.L., Costa G.G., Cialdella S. et al. (2018) Return to Sports after Unicompartmental Knee Arthroplasty: Reality or Utopia? A 48-Month Follow-Up Prospective Study. J. Knee Surg., 1-6. doi.org/10.1055/s-0038-1635111.

2. Sun X., Su Zh. (2018) A meta-analysis of unicompartmental knee arthroplasty revised to total knee arthroplasty versus primary total knee arthroplasty. J. Orthopaed. Surg. Res., 13(158): 1-9. doi.org/10.1186/s13018-018-0859-1.

3. Kamenaga T., Hiranaka T., Kikuchi K. et al. (2018) Influence of tibial component rotation on short-term clinical outcomes in 0xford mobile-bearing unicompartmental knee arthroplasty. Knee, 1-9. doi.org/10.1016/j.knee.2018.06.016.

4. Murray D.W., Parkinson R.W. (2018) Usage of unicompartmental knee arthroplasty. Bone Joint J., 100-B: 432-435. doi:10.1302/0301-620X.100B4. BJJ-2017-0716.R1.

5. Wada K., Hamada D., Takasago T. et al. (2018) Native rotational knee kinematics is restored after lateral UKA but not after medial UKA. Knee Surgery, Sports Traumatology, Arthroscopy, 1-6. doi.org/10.1007/s00167-018-4919-1.

6. Campi S., Tibrewal S., Cuthbert R., Tibrewal S.B. (2017) Unicompartmental knee replacement - Current perspectives. J. Clin. Orthop. Trauma, 1-7. doi.org/10.1016/j. jcot.2017.11.013.

\section{Significance of risk factors related to the features of knee osteoarthritis in forecasting long- term results of unicompartmental knee replacement \\ M.M. Matsipura}

National Pirogov Memorial Medical University, Vinnytsia, Ukraine

Abstract. Aim: to establish the prognostic value of risk factors associated with the peculiarities of knee osteoarthritis in relation to the long-term results of unicompartmental knee replacement. Materials and methods. Long-term results of unicompartmental knee replacement in 99 patients with medial knee osteoarthritis were analyzed $26(26.26 \%)$ men and $73(73.74 \%)$ women. The average age was $63.78 \pm 8.21$ years. According to the results of the Oxford Knee Score questionnaire, 4 groups were formed. Group 1 included 62 (62.63\%) patients without progression of knee osteoarthritis in long-term period. Mild manifestations of knee osteoarthritis were found in 23 (23.23\%) patients of group 2, moderate - in 10 (10.10\%) examined 3 groups, and 4 (4.04\%) patients of group 4 recorded severe manifestations of the disease. The average result of treatment in the remote period was $37.65 \pm 7.89$. Risk factors such as pathogenetic variants of osteoarthritis, previous joint surgery, stage, duration of the disease before surgery and duration of the postoperative period were assessed. "Statistica 13» was used for statistical analysis. Results. It was found that the duration of the disease before surgery $\leq 5$ years (odds ratio (OR) 2.70; 95\% confidence interval $(\mathrm{Cl}) 1.11-6.58 ; \mathrm{p}=0.02)$ and the duration of the postoperative period $\leq 5$ years $(\mathrm{OR} 5.01 ; 95 \% \mathrm{Cl}$ $1.90-13.20 ; p=0.0007$ ) increase the chances of no progression of knee osteoarthritis in the long term. Instead, the presence of previous operations in the knee joint (OR 12.0; $95 \% \mathrm{Cl} 1.15-125.52 ; \mathrm{p}=0.02)$ are associated with the progression of knee osteoarthritis. Conclusion. The high prognostic value of risk factors associated with the peculiarities of knee osteoarthritis in assessing the long-term results of unicompartmental knee replacement has been proven.

Key words: unicompartmental replacement, knee joint, knee osteoarthritis, risk factors, degenerative-dystrophic joint diseases.

\section{Information about the author:}

Matsipura Maxim M. — graduate student of the Department of Traumatology and Orthopedics, National Pirogov Memorial Medical University, Vinnytsia, Ukraine. ORCID ID: 0000-0002-56318056

\section{Address for correspondence:}

Maxim Matsipura

21032, Vinnytsia, Tchaikovsky str., 13, apt. 81

E-mail:dr.matsipura@gmail.com 